\title{
Carbon Supply Reduction has a Minimal Influence on Current Year's Red Raspberry (Rubus idaeus L.) Fruit Production
}

\author{
Gina E. Fernandez and Marvin P. Pritts \\ Department of Fruit and Vegetable Science, Cornell University, Ithaca, NY 14853 \\ Additional index words. canopy manipulation, carbon allocation, carbon assimilation, light, partitioning, shading, source-sink
}

\begin{abstract}
A 2-year study was conducted to investigate the influence of the light environment on source-sink relationships in 'Titan' red raspberry. Treatments imposed included flower and cane removal in conjunction with partial or whole canopy shading. Raspberry plants were remarkably resistant to a reduction in carbon supply. Yields and primocane production were maintained even when canopies were shaded. Furthermore, if raspberry plants were prevented from producing a full crop in one year, yields the following year tended to be higher than normal. These data, and other studies demonstrating that raspberry roots are strong carbon sinks, suggest that raspberry plants may rely on stored carbohydrate to mature the current crop of fruits when current photosynthate is inadequate. This trait is characteristic of some perennial species adapted to progressively changing environments, but may not be optimal for horticultural situations where growing conditions are relatively constant from year to year. A large root storage capacity and excessive primocane production likely contribute to the relatively low yields that are typical of this species.
\end{abstract}

Natural populations of perennial plants experience wide variation in resource availability during their lifetimes, so they tend to exhibit plasticity in morphological, physiological, and reproductive responses to environment (Bazzaz et al., 1987). Many of these plastic responses are likely the result of natural selective forces operating on plant populations, favoring the capacity to shift carbon partitioning to various plant parts as resource availability varies over time. When perennial plants are domesticated, such plastic responses may no longer be beneficial, and actually may limit the performance of plants in agricultural situations where resources are always available at relatively high levels and survivorship is ensured. For example, vegetative reproduction or extensive carbohydrate storage capacity can be beneficial when resource availability varies from year to year, but these same traits may not be useful in some agricultural situations if they exact a physiological cost or if a trade-off exists with the edible portion of the plant.

Raspberries are recently domesticated plants that exhibit extreme plasticity under natural conditions (Abrahamson, 1975; Whitney, 1982). Raspberry plants are known to shift carbon allocation among fruits when sinks are manipulated (Gundersheim and Pritts, 1991; Nehrbas and Pritts, 1988a), but this does not ensure that yields will be high when fruit numbers are low. In general, reproductive effort of red raspberry is always low (Fernandez and Pritts, 1994; Whitney, 1982). Explanations for this low harvest index have ranged from self-shading (Wright and Waister, 1984) to intraplant competition (Waister et al., 1977) to the convergence of sink demand during fruiting (Fernandez and Pritts, 1994). However, before the causes of low yield can be identified with certainty, source-sink relationships within the entire plant need to be understood.

The raspberry plant is a unique model with which to study relationships among plant parts because it has well-defined cane

Received for publication 28 July 1995. Accepted for publication 17 Dec. 1995. Department of Fruit and Vegetable Science paper no. 48. Supported by Hatch Project NY 142-402. We gratefully acknowledge the technical assistance of Mary Jo Kelly and Caitlan Morse, and the helpful reviews of Ian Merwin, Mary Jo Kelly, Rebecca Darnell, and J.S. Cameron. The cost of publishing this paper was defrayed in part by the payment of page charges. Under postal regulations, this paper therefore must be hereby marked advertisement solely to indicate this fact. types that serve different physiological functions. First year canes (primocanes) serve as a mechanism for vegetative reproduction. Also, as they grow to the top of the plant canopy, they supply the root system with photosynthate (Fernandez and Pritts, 1994; Whitney, 1982). In the second year, these canes (floricanes) make no extension growth, but produce fruiting laterals before senescing.

We were interested in learning how raspberry plants respond to manipulations of carbon sources and sinks under different environmental conditions. Our approach was to manipulate sources and sinks in one year, then measure vegetative and fruiting responses over two years. At the same time, we measured these responses under altered light conditions. Based on previous studies suggesting that roots are a strong carbon sink (Fernandez and Pritts, 1993, 1994), we hypothesized that accumulated carbohydrate can help mature a subsequent crop under resource limited conditions. If little carbohydrate storage occurs, then we would expect carbon source reduction treatments to have immediate effects on growth and yield. If plants have stored carbohydrate available to them, then we would not expect to observe treatment effects under source limited conditions until a later time, if at all. Knowing this type of information should help horticulturists develop better models of raspberry plant growth and production, and lead to changes in cultural practices that would improve resource use efficiency. Furthermore, such studies could help to identify certain physiological responses that breeders could modify to improve long term productivity.

\section{Materials and Methods}

Source-sink relationships were altered in fruiting raspberry plants by treatments that included flower removal, primocane or floricane removal, or a combination thereof. Superimposed were treatments in which floricanes or primocanes were shaded independently. Yields, growth responses, and leaf gas exchange were measured in the year treatments were imposed, and in the subsequent year.

Experimental design and treatment description. Three $40 \mathrm{~m}$ rows of 'Titan' red raspberry (Sanford et al., 1985), established in 1986, in an east-west orientation were selected for this study. The plants were located at Cornell Orchards, Ithaca, N.Y., and were 


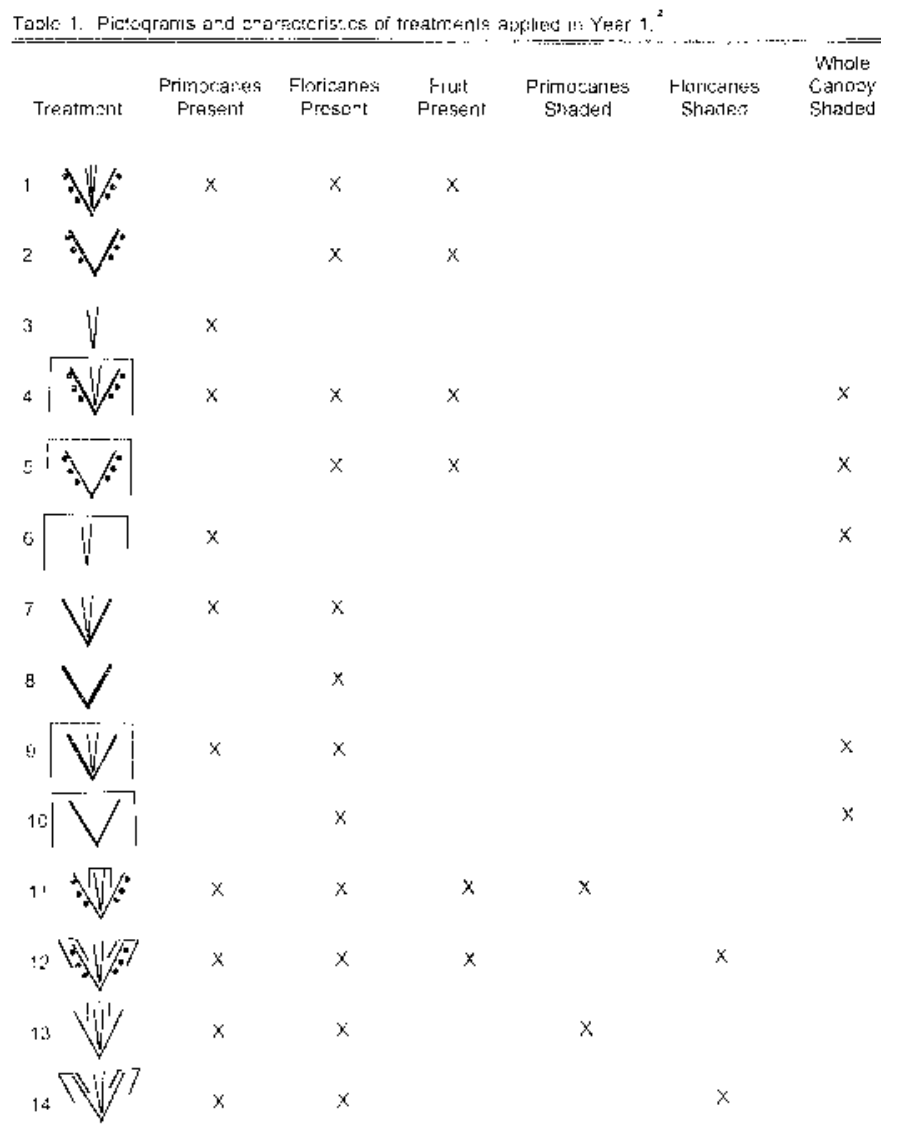

$\overline{{ }^{2} \text { Thick widely-angled lines represent floricanes, solid circles indicate }}$ fruit, thin narrowly-angled lines indicate primocanes, and the remaining lines indicate how the various cane types were shaded.

growing in a Collamer fine-silty loam (Glossoboric Hapludalf), which was moderately well drained. Pest control and nutritional needs throughout the study were addressed following standard recommendations (Pritts and Handley, 1989). All plots were supplied with water as needed through drip irrigation.

In the spring of 1991 (Year 1), eight floricanes were selected per plant and were pruned to about $1.5 \mathrm{~m}$ in height and trained to a Vwire trellis, with a maximum spread of $1.0 \mathrm{~m}$ at $1.0 \mathrm{~m}$ from the ground. All other floricanes were removed from the plots. Fourteen treatments were applied to $0.8-\mathrm{m}^{2}$ plots with a $1.0-\mathrm{m}^{2}$ buffer separating each plot in a randomized block design with 3 replications. Treatments applied in Year 1 included shading of primocanes, floricanes, or the entire canopy, in combination with removal of primocanes, floricanes, or fruit (Table 1). Shading of floricanes and primocanes was achieved with $63 \%$ polypropylene black shade cloth (Chicopee shade cloth; A.H. Hummert, St. Louis) suspended $2.0 \mathrm{~m}$ above ground. Shade cloth was positioned perpendicular to the row orientation, so the north, south, and top of the canopy were shaded. The east and west sides were left open to allow for air circulation and free movement of pollinators in and out of the plots. Shade treatments were present on whole or partial canopies from 11 May (lateral elongation) to 24 Sept. 1991 (maximum primocane extension). Maximum light intensity under the shade cloth was about $700 \mu \mathrm{mol} \cdot \mathrm{m}^{-2} \cdot \mathrm{s}^{-1}$. All primocanes were removed at least once per month from appropriate treatments $(2,5$, 8 , and 10) in Year 1. Developing flowers were removed 4 June, 17 June and 3 July 1991 from appropriate treatments $(7,8,9,10,13$, and 14).

In 1992 (Year 2), no treatments were applied to the plots, nor were any floricanes (last year's primocanes) removed from plots. However, floricanes were pruned to $1.5 \mathrm{~m}$ and trained to the same $\mathrm{V}$-wire trellis as described previously.

Temperature and relative humidity were monitored both years with a data logger (Sensor instruments, Concord, N.H.) at two separate locations in the plots. One location was unshaded and another had the entire canopy shaded.

Cane growth and yield data. In Year 1, the number of canes removed was recorded at each primocane removal date. Ripe fruit was harvested twice a week from treatments with floricanes $(1,2$, $4,5,11$, and 12) in Year 1, and from treatments with floricanes in Year $2(1,3,4,6,7,9,11,12,13$, and 14) (Table 1). Fruit count/ cane, fruit fresh, and dry weights were recorded in both years. There was no evidence of poor pollination due to the obstruction of insects by the shade cloth in Year 1.

Gas exchange. Carbon dioxide assimilation rates $\left(\mu \mathrm{mol} \cdot \mathrm{m}^{-2} \cdot \mathrm{s}^{-1}\right.$, A) of primocane and floricane leaves were obtained using a portable gas exchange system (model 6200; LI-COR, Lincoln, Neb.) All measurements were made about 3 to $5 \mathrm{~h}$ after sunrise, during the first and second growing seasons, on 3 dates, before, during and after fruiting. One recently expanded primocane leaf and a floricane leaf exposed to full sun were used for gas exchange measurements. Shade cloth was removed from the treatments 11-15 min before measurements were taken to ensure maximum $\mathrm{A}$ under ambient light conditions. In some instances, to obtain A from as many treatments as possible, measurements had to be taken on 2-3 consecutive sunny days.

Analysis of canopy structure. In the third growing season, floricanes were trellised as described above in an adjacent row of 'Titan' not used in previous manipulations. Canopy structure in one $3.0 \mathrm{~m}$ plot was quantified with primocanes present and in another without, using a plant canopy analyzer (PCA) (model LAI2000; LI-COR) on 8 May, 18 May, 25 June, 25 July, and 26 Aug. A single reading was taken above the canopy and then a series of five measurements were taken in a diagonal across the row, that extended about $3.0 \mathrm{~m}$ from the middle of aisle, the edge of the row, the center of the row, the other edge of the row and the opposite center aisle. These six measurements were then integrated by the PCA into a single measure to describe canopy structure. These series of measurements were taken at $0.5 \mathrm{~m}$ above the ground and at ground level. PCA measurements were obtained with the instrument operator facing east. A field of view delimiter (75\% closed facing the operator) was used for all observations to avoid erroneous inclusion of the operator's image in data collection. All measurements were taken between 1100 and 1200 HR on cloudy days to avoid non-uniformity of sky brightness, and averaged across the season.

\section{Results}

Despite some rather extreme manipulations of sources and sinks (Table 1), the raspberry plants were able to produce normal crops when fruiting sinks were present (Fig. 1), and they produced relatively constant numbers of primocanes across treatments in Year 1 (17.6 \pm 3.7$)$ and again in Year $2(14.9 \pm 2.14)$. However, treatments producing low yields in Year 1 tended to produce high yields in Year 2, and vice versa (Table 2). Floricane leaf A in both years was unaffected by any treatment, although primocane A was responsive to certain manipulations as described below. Some growth responses under full sun conditions were negated when shading was imposed. Shaded and unshaded plots differed little in air temperature and humidity (data not shown), despite differences in radiation. 


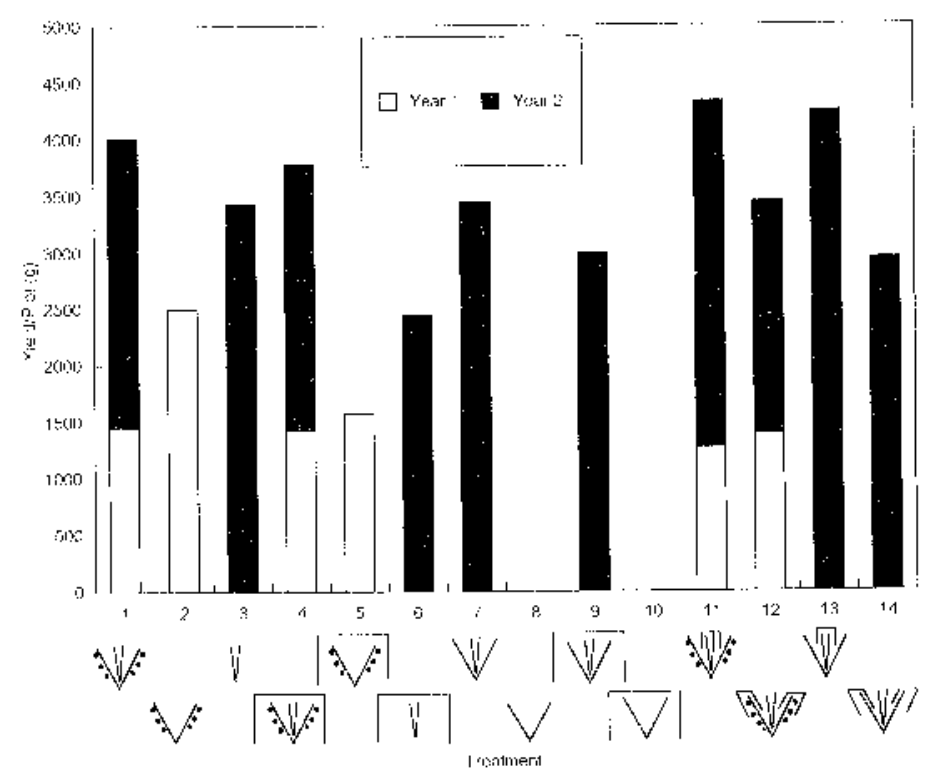

Fig. 1. Yield response in consecutive years to treatments imposed in Year 1. (See Table 1 for a more detailed description of treatments). LSD $_{(0.05)}$ for Year $1=738$; Year 2 yields are not significantly different.

The response to deflowering. Flower removal obviously eliminated yield for the current year, but productivity in plants the year after deflowering tended to be higher than the yield of control plots in Year 2, regardless of shading (Fig. 1, treatments 1 and 4 vs. 7 and $9, P<0.10)$. Stronger effects were observed when the yields of all treatments in Year 1 were correlated with Year 2 yields. Treatments with lower than average yields or small yield components in one year had higher than average yields the following year, and vice versa $(r=-0.68, P<0.05$, Table 2$)$.

Under unshaded conditions, deflowering did not significantly affect primocane numbers or primocane $\mathrm{A}$ in either year (Year 1 mean, $7.97 \mu \mathrm{mol} \cdot \mathrm{m}^{-2} \cdot \mathrm{s}^{-1} \pm 2.10$; Year 2 mean, $9.22 \mu \mathrm{mol} \cdot \mathrm{m}^{-2} \cdot \mathrm{s}^{-1} \pm$ 2.63), or floricane A in Year 2 (23 May mean, $8.69 \mu \mathrm{mol} \cdot \mathrm{m}^{-2} \cdot \mathrm{s}^{-1} \pm$ $1.39 ; 24$ Aug. mean, $\left.4.34 \mu \mathrm{mol} \cdot \mathrm{m}^{-2} \cdot \mathrm{s}^{-1} \pm 0.54\right)$. However, in Year 1, floricane A was significantly greater in fruiting plants until harvest. For example, on 10 June 1991, maximum A for fruiting plants was $8.4 \mu \mathrm{mol} \cdot \mathrm{m}^{-2} \cdot \mathrm{s}^{-1}$ while deflowered plants averaged 5.6 $\mu \mathrm{mol} \cdot \mathrm{m}^{-2} \mathrm{~s}^{-1}$.

Response to primocane removal. Primocane removal had dramatic effects on yield in Year 1. In unshaded plots, the primocane removal treatment had the highest Year 1 yield compared to all others (Fig. 1, $P<0.05$ ). The fraction of sky visible through the canopy was greater when primocanes were removed (Fig. 2), suggesting that light distribution on floricane leaves was higher with this treatment. Maximum A on a leaf area basis was unaffected, however. The significant yield increase in Year 1 that resulted from primocane removal (treatment 1 vs. 2) was negated when the canopy was shaded (treatment 1 vs. 5). Primocane

Table 2. Correlation coefficients between yield components for Years 1 and 2.

\begin{tabular}{lc}
\hline \hline Yield component & $r^{2}$ \\
\hline Yield & -0.68 \\
Fruit number/plant & -0.70 \\
Mean individual fruit weight & -0.38 \\
Yield/cane & -0.51 \\
Mean fruit number/cane & -0.70 \\
\hline
\end{tabular}

${ }^{\mathrm{z}} \mathrm{All}$ correlations are significant at $P<0.05$.

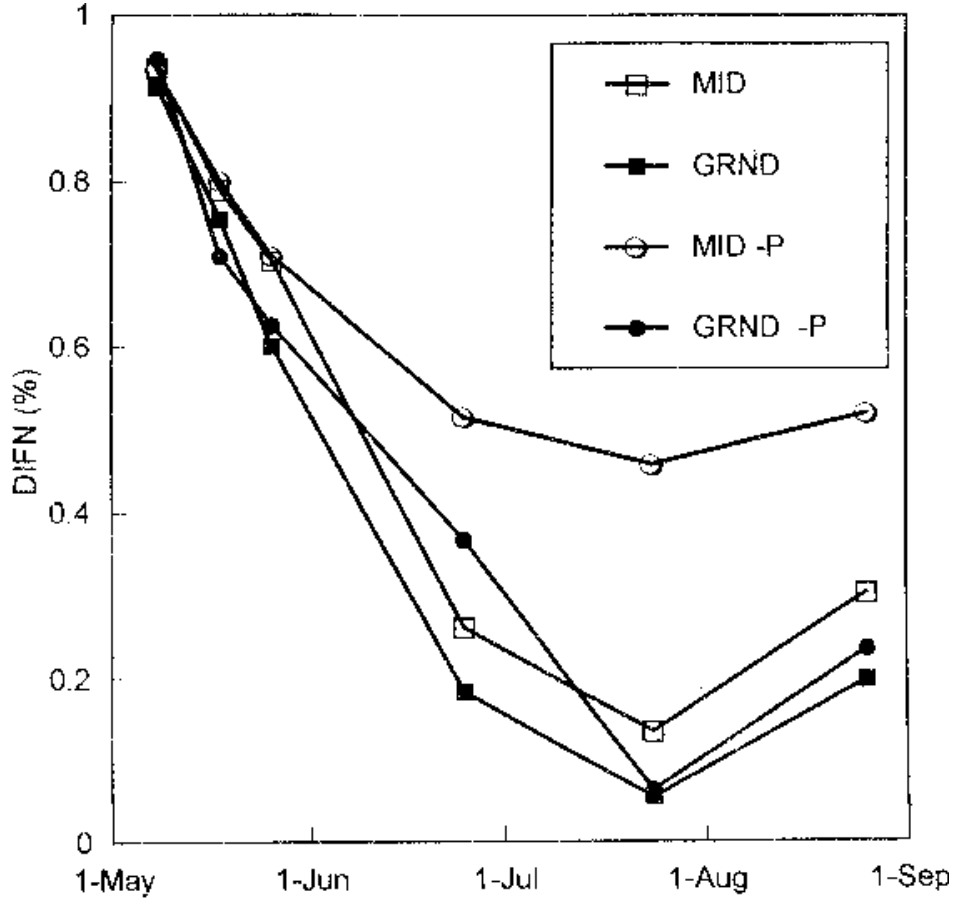

Fig. 2. Seasonal changes in the fraction of sky visible beneath the canopy (DIFN) at $0.5 \mathrm{~m}$ above ground level (MID; open squares with primocanes, solid squares without primocanes) or at ground level (GRND; open circles with primocanes, solid circles without primocanes).

removal in Year 1 had no effect on floricane or primocane A in either year (data not shown).

Response to floricane removal. Maximum A of primocane leaves was about $34 \%$ higher throughout the season when floricanes were removed compared to unpruned plants $(P<0.05)$, but in Year 2 , primocanes from plants that had floricanes removed the previous year had reduced A early in the season (e.g. 9.95 vs. 5.24 $\mu \mathrm{mol} \cdot \mathrm{m}^{-2} \cdot \mathrm{s}^{-1}$ on 23 May $\left.1992, P<0.05\right)$. Floricane A in Year 2 was not affected - the seasonal decline in A was the same regardless of Year 1 treatment (from a mean of $6.13 \mu \mathrm{mol} \cdot \mathrm{m}^{-2} \cdot \mathrm{s}^{-1}$ on 7 June 1992 to 1.73 on 6 Sept.).

Primocane production was not influenced by the removal of floricanes under any of the various light conditions that we imposed, and yields in the second year were not affected significantly.

\section{Discussion}

In most perennial plants, rapid root growth is not synchronous with fruiting; flowers and fruit are supplied preferentially with photosynthate, followed by cambial tissue, then roots (Larcher, 1975). In raspberry, accumulation of starch begins and root growth accelerates while plants are flowering and fruiting, and this accumulation continues into the fall (Fernandez and Pritts, 1994; Whitney, 1982). A strong root sink is likely to affect the way a plant responds to environmental stresses and levels of input. We hypothesize that a large accumulation of carbohydrate in the root of red raspberry can be used to mature the following year's crop if carbon supply is limited then, but also can limit yield in any one year. We have circumstantial evidence to support this hypothesis. When plants are subjected to moderate shade, yields and primocane production are not affected. When plants are manipulated to have no yield in one year, productivity the following year tends to be higher, and vice versa (Fig. 1). A negative relationship exists between yield components in consecutive years (Table 2). These 
patterns would be expected if stored carbohydrates are expended to mature a crop under source-limited conditions. Waister et al. (1977) and Wright and Waister (1984) found this same pattern in other cultivars of red raspberry, and such patterns are common in natural plant populations (Bazzaz, et al., 1987; Harper, 1977) and in other cultivated perennial crops (Forshey and Elfving, 1989; Kozlowski, et al., 1991; Tustin, et al., 1992).

The most interesting result of our study was how similar yields and primocane numbers were in Year 1 under fairly intensive manipulations of sources and sinks. For example, current year's yield was unaffected by shading, and primocane numbers were unaffected by deflowering, floricane removal, or whole plant shading in either year. Only when primocanes were completely removed did current year's yield increase.

The effect of complete primocane removal on yield was negated under shaded conditions. This was the only significant direct effect of shading that we measured. Although primocanes partially shade the floricanes, they also appear to contribute photosynthate to the root system (Fernandez and Pritts, 1993), which could be used eventually by the floricanes. Therefore, under shaded conditions, the increased exposure of floricane leaves to available light when primocanes are removed does not appear to offset the overall increase in photosynthate production by plants with primocanes. This observation suggests that a trellising system that exposes floricanes to high light while retaining primocanes for next year's crop could be an effective strategy for increasing long term yield.

Balancing the numbers of primocanes and floricanes is another strategy that can improve carbon balance and light distribution within the canopy. For example, a grower could remove or suppress a fraction of the primocanes while allowing a sufficient number to develop for next year's crop. This strategy would increase light interception of floricanes and hence, yield, while maintaining future cropping potential.

Maximizing light interception of floricanes at the expense of primocanes, if necessary, may be an effective strategy to maximize long term productivity in red raspberry. Several additional observations support this proposition: 1) floricane leaves have a shorter life than primocane leaves, so floricanes should receive higher light levels early in the season to maximize their carbon contribution, 2) floricanes exposed to higher light levels tend to have higher yields (Nehrbas and Pritts, 1988 a, b), 3) primocanes have a lower light saturation point than floricanes (Fernandez and Pritts, 1994), 4) most cultivars produce excessive primocanes that are intentionally reduced in number by pruning, and 5) carbon fixed by primocane leaves appears to contribute to root growth rather than directly to the current year's crop (Fernandez and Pritts, 1993). In many cases, current trellising and pruning practices could be improved to increase floricane light interception.

Primocane, floricane, and flower removal directly affect cropping patterns, but our data show that photosynthesis can be affected as well. For example, primocane leaf A was significantly higher when floricanes were removed at the beginning of the season. Normally, primocanes develop under the intense shade of floricanes. The higher A observed with floricane removal is consistent with observations in many species whose leaves develop in full sun tend to have a higher maximum A than leaves which develop in shade (Boardman, 1977; Kozlowski, et al., 1991; Osmond and Chow, 1988). Primocanes account for a large amount of shading in the lower canopy (Fig. 2). Floricanes are likely to account for even more shading since they are at full height at the beginning of the season. Therefore, it is not surprising that manipulations of primocanes and floricanes had larger effects than the imposition of $63 \%$ shade cloth.
An effect of floricane removal on primocane A also was measured early in the second season; A was lower in plants that had their floricanes removed the previous year. This observation is consistent with our hypothesis that stored carbohydrates would be very high in plants that did not fruit the previous year, so there would be less demand on primocanes for photosynthate the following year. This resulted in a reduction in A until carbohydrate demand increased later in the season.

Our observation that shading has little effect on intact red raspberry plants is consistent with responses observed in some woody plants in natural habitats. Kozlowski et al. (1991) discuss the tendency of certain woody plant species to incorporate an excessive amount of photosynthate into roots at the expense of the harvestable portion. Although the ability to store large amounts of carbohydrate for use the following year would help to buffer the plant against environmental extremes, such as shading, herbivory, and other stresses, it also might reduce fruiting potential in any one year. For example, the tendency of raspberries to overproduce primocanes enables the plant to tolerate shading and some loss of foliage, but it is of little value in horticultural situations where plants are generally exposed to full sun and herbivore outbreaks are controlled. Furthermore, pruning excessive primocanes is costly to the grower and the presence of primocanes reduces yield in the current year due to internal shading of floricanes. Even under near ideal conditions, the harvest index of red raspberries is low, about 5\% (Fernandez and Pritts, 1994).

In summary, our observations are consistent with the hypothesis that the red raspberry stores large amounts of carbohydrate in the root that can be remobilized to floricanes during fruiting or stored for use the following year. Consequently, the effects of a reduction in assimilated carbon in any one year tend to be minimal. This storage capacity is useful if resource levels are unpredictable or changing over time, but may not be beneficial under consistently favorable agricultural conditions.

Plant breeders may want to consider a plant type that produces fewer primocanes, is less shade tolerant, and has a much higher harvest index. The cultivar Titan produces fewer primocanes than the typical raspberry, and its yields are relatively high. Perhaps this genotype is closer to the physiological ideotype than most others, but it is still far from the ideal. Until genotypes are developed that exhibit altered fruit and root sink strength, cultural efforts are best directed at maximizing the light exposure of floricanes.

\section{Literature Cited}

Abrahamson, W.G. 1975. Reproductive strategies in dewberries. Ecology 56:721-726.

Bazzaz, F.A., N.R. Chiariello, P.D. Coley, and L.F. Pitelka. 1987. Allocating resources to reproduction and defense. Bioscience 37:58-67.

Boardman, N.K. 1977. Comparative photosynthesis of sun and shade plants. Ann. Rev. Plant Physiol. 28:355-377.

Fernandez G.E. and M.P. Pritts. 1993. Growth and source-sink relationships in 'Titan' red raspberry. Acta Hort. 325:151-157.

Fernandez G.E. and M.P. Pritts. 1994. Growth, carbon acquisition and source-sink relationships in 'Titan' red raspberry. J. Amer. Soc. Hort. Sci. 119:1163-1168.

Forshey, C.G. and D.C. Elfving. 1989. The relationship between vegetative growth and fruiting in apple trees. Hort. Rev. 11:229-287.

Gundersheim, N. and M. Pritts. 1991. Pruning practices affect yield, yield components, and their distribution in 'Royalty' purple raspberry. J. Amer. Soc. Hort. Sci. 116:390-395.

Harper, J.L. 1977. Population biology of plants. Academic Press, New York.

Kozlowski, T.T., P.J. Kramer, and S.G. Pallardy. 1991. The physiological ecology of woody plants. Academic Press, New York. 
Larcher, W. 1975. Physiological plantecology. Springer-Verlag, New York.

Nehrbas, S.R. and M.P. Pritts. 1988a. Effect of pruning system on yield components of two summer-bearing raspberry cultivars. J. Amer. Soc. Hort. Sci. 113:314-321.

Nehrbas, S.R. and M.P. Pritts. 1988b. Effect of training system on performance of hand-harvested summer-bearing raspberries. HortScience 23:126-127.

Pritts, M. and D. Handley. (eds). 1989. Bramble production guide. Northeast Regional Agr. Eng. Serv., Ithaca, New York.

Sanford, J.C., D.K. Ourecky, and J.E. Reich. 1985. 'Titan' red raspberry. HortScience 20:1133-1134.

Osmond, C.B. and W.S. Chow. 1988. Ecology of photosynthesis in the sun and shade: Summary of prognostications. Austral. J. Plant Phys.
15:1-9.

Tustin, S., L. Corelli-Grappadelli, and G. Ravaglia. 1992. Effect of previous season and current light environment on early spur development and assimilate translocation in 'Golden Delicious' apple. J. Hort. Sci. 67:351-360.

Waister, P.D., M.R. Cormack, and W.A. Sheets. 1977. Competition between fruiting and vegetative phases in the red raspberry. J. Hort. Sci. $52: 75-85$.

Whitney, G.G. 1982. The productivity and carbohydrate economy of a developing stand of Rubus idaeus. Can. J. Bot. 60: 2697-2703.

Wright, C.J. and P.D. Waister. 1984. Light interception and fruiting cane architecture in red raspberry grown under annual and biennial management systems. J. Hort. Sci. 59:395-402. 